\title{
Intertekstual Novel Senja, Hujan dan Cerita yang Telah Usai Karya Boy Candra dan Novel Hujan Karya Tere Liye
}

\author{
Mitasari \\ Pendidikan Bahasa dan Satra Indonesia Universitas Muhammadiyah Jember \\ mitasarim30@gmail.com
}

DOI: http://dx.doi.org/10.32528/bb.v5i1.3064

Diterbitkan: 30-03-2020

\begin{abstract}
ABSTRAK
Penelitian ini bertujuan untuk mendeskripsikan hubungan intertekstualitas antara novel Senja, Hujan, dan Cerita yang Telah Usai Karya Boy Candra dan Novel Hujan Karya Tere Liye. Jenis penelitian ini adalah deskriptif kualitatif dengan data yang dikumpulkan berupa peristiwa yang merupakan hasil persamaan dan perbedaan tema dan alur dari kedua novel. Hasil penelitian ini menunjukka bahwa terjadi kesamaan dalam kedua novel yaitu tema hujan yang menjadi simbol penanda kenangan masa lalu dan alur yang digunakan adalah alur campuran. Dasar kesamaan tema dan alur didukung oleh kesamaan peristiwa-peristiwa dalam cerita menunjukkan adanya hubungan intertekstual antara kedua novel. Sebagai karya yang terbit terebih dahulu novel Senja, Hujan, dan Cerita yang Telah Usai karya Boy Candra adalah hipogram dan novel Hujan karya Tere Liye sebagai transformasi. Pada tema dan alur, tranformasi novel Hujan sedikit meneruskan dan banyak menyimpangi hipogramnya.
\end{abstract}

Kata kunci : intertekstual; hipogram; transformasi

\begin{abstract}
This study aims to describe the intertextuality relationship between the novel Senja, Hujan, dan Cerita yang Telah Usai Karya Boy Candra and Novel Hujan Karya Tere Liye. This type of research is descriptive qualitative with data collected in the form of events that are the result of similarities and differences in themes and plot of the two novels. The results of this study indicate that there are similarities in both novels, namely the theme of rain which is a symbol of past memories and the plot used is a mixed plot. The basis of the similarity of themes and plot is supported by the similarity of events in the story showing an intertextual relationship between the two novels. As the first published work of the novel Senja, Hujan, dan Cerita yang Telah Usai karya Boy Candra is a hipogram and the novel Hujan Karya Tere Liye as a transformation. On the theme and plot, the transformation of the novel Rain continues a little and deviates much from the hipogram.
\end{abstract}

Keywords: intertextual; hipogram; transformation 


\section{PENDAHULUAN}

Sebuah teks karya sastra senantiasa berada di antara teks-teks lain yang mendahuluinya, sehingga terjalin relasi yang interstekstual (Teeuw dalam Sungkowati : 2014). Intertekstualitas pertama kali dikenalkan oleh Julia Kristeva yang mengembangkan pemikiran Michael Bakhtin seorang Filsuf Rusia sebagai teori yang menyatakan bahwa sebuah teks harus dibaca dengan latar belakang lain, dikarenakan sebuah teks tidak benar-benar dapat berdiri sendiri tanpa adanya teks lain sebagai teladan. Kristeva (dalam Rokhmansyah, 2014, hal 119) menegaskan dua alasan perihal munculnya teori intertekstual. Alasan pertama, pengarang adalah pembaca teks sebelum menciptakan atau menulis teks. Sedangkan alasan yang kedua, sebuah teks tersedia hanya melalui proses pembacaan. Kemungkinan adanya penerimaan atau pertentangan terletak pada pengarang melalui proses pembacaan.

Menurut Kristeva setiap teks, termasuk teks sastra merupakan mozaik kutipan dan tanggapan atau penyerapan teks-teks lain. Oleh karena itu, Teeuw (dalam Rokhmansyah, 2014, hal 119) juga menegaskan bahwa suatu teks baru bermakna penuh dalam hubungannya dengan teks-teks lain. Sedangkan menurut Riffaterre (dalam Rokhmansyah, 2014, hal 121) juga berpendapat bahwa teks tertentu yang menjadi latar penciptaan teks baru disebut hiprogram, sedangkan teks yang menyerap hiprogram disebut transformasi. Hubungan antara teks terdahulu dengan teks yang kemudian inilah yang sebut dengan hubungan intertekstual. Berdasarkan pendapat di atas dapat disimpulkan bahwa kajian intertekstual adalah fenomena resepsi pengarang terhadap teks-teks yang pernah dibacanya kemudian dilibatkan dalam hasil karyanya.

Saat membaca suatu novel, pembaca sering kali merasa pernah membaca novel lain yang memiliki jalan cerita yang mirip. Beberapa novel juga pasti dirasa memiliki kesamaan tokoh, alur, dan latar yang hampir mirip. Untuk mengetahui kesaamaan dan perbedaan dalam novel-novel itulah diperlukan kajian intertekstualitas. Melalui kajian intertekstual itu pulalah dapat diketahui novel mana yang menjadi hipogram, dan novel mana yang menjadi transformasi. Tujuan kajian intertekstual sendiri tidak untuk membedakan hasil karya seorang pengarang, melainkan untuk melihat seberapa jauh kreativitas pengarang.

Terkait dengan fenomena adanya kemiripan alur dan tema dalam beberapa novel, penelitian ini akan melihat sejauh mana keterkaitan cerita dalam novel Senja, Hujan, dan Cerita yang Telah Usai karya Boy Candra dan novel Hujan karya Tere Liye. Dua novel tersebut diasumsi memiliki kemiripan dalam karakteristik alur dan tema. Sehingga diprediksi kedua novel tersebut memiliki hubungan intertekstualitas. Oleh karena itu, pada penelitian ini peneliti mengulas tentang "Kajian Intertekstual Novel Cerita yang Telah Usai karya Boy Candra dan Novel Hujan karya Tere Liye". Adapun penelitian yang sejalan dengan penelitian ini adalah pengaruh cerita Laskar Pelangi terhadap Negeri 5 Menara karya Uniawati dan Pengakuan Calabay karya Kusuma, Waluyo, dam Wardani.

Novel Senja, Hujan dan Cerita yang Telah Usai karya Boy Candra atau selanjutnya disingkat SHC lebih dulu terbit pada tahun 2015, mengisahkan seorang lelaki yang ingin melupakan semua kisah cinta yang terpendam terhadap sahabat 
perempuannya. Sedangkan Novel Hujan karya Tere Liye atau yang selanjutnya disingkat $\mathrm{H}$ terbit pada tahun 2016, mengisahkan seorang perempuan yang ingin menghapus semua ingatan masa lalunya melalui terapi mesin. Kedua novel tersebut juga memiliki alur yang sama yaitu flashback atau menceritakan kenangan-kenangan bersama seseorang yag berarti bagi hidup tokoh utama.

Kehadiran kedua novel tersebut cukup ditunggu oleh pembaca, mengingat kedua pengarang novel tersebut sama-sama memiliki nama yang besar di Indonesia. Boy Candra selalu ditunggu penggemarnya melalui puisi-puisi romantisnya yang selalu diunggah di akun youtube pribadinya, sedangkan Tere Liye selalu ditunggu kata-kata romantisnya di akun media sosialnya. Sehingga kripah kedua penulis hingga saat ini masih digandrungi semua kalangan masyarakat, terutama generasi milenial.

Persamaan dan perbedaan dalam kedua novel tersebut sangat menonjol. Persamaan dan perbedaan itu pulalah yang menjadi titik tolak dan kekuatan masing masing novel. Persamaan kedua novel tersebut terdapat pada tema yang sama-sama menggambarkan tentang kenangan-kenangan tokoh utama terhadap hujan. Persamaan yang lain, terdapat pada alur cerita, alur cerita yang digunakan pada kedua novel tersebut adalah alur campuran. Sedangkan perbedaan pada kedua novel tersebut dapat dilihat dari sudut pandang dan tokoh dalam cerita. Persamaan dan perbedaan inilah yang mengandung unsur hubungan intertekstual.

Persamaan-persamaan yang terdapat dalam novel, bisa saja terjadi karena kesamaan biografi pengarang meskipun secara tidak sengaja. Kedua pengarang samasama berjenis kelamin laki-laki, lahir di Pulau Sumatra, menggeluti pendidikan yang non sastra, serta sama-sama mulai aktif menulis fiksi sejak Sekolah Dasar. Adapun perbedaan-perbedaan yang terdapat dalam novel adalah sebagai bentuk kreativitas dalam kajian intertekstual.

Berdasarkan perihal yang melatarbelakangi terjadinya kajian intertekstual, peneliti menyakini bahwa kajian intertekstual bisa digunakan sebagai salah satu alternatif bahan ajar pada siswa tentang menulis karya sastra. Mengingat penulis yang memiliki latar belakang yang sama, bisa memiliki persamaan dalam menulis karya sastra. Siswa yang ada disekolah juga memiliki latar belakang yang sama, yaitu guru yang mengajar adalah orang yang sama. Sehingga guru bisa mengunakan kajian intertekstual pada materi menulis sastra. Siswa terlebih dahulu mengamati hasil karya sastra milik orang lain untuk menemukan ide dalam menulis. Setelah itu siswa dipersilahkan membuat karya sastranya sendiri dengan gaya dan kreativitasnya masingmasing.

\section{METODE PENELITIAN}

Metode penelitian ini adalah metode deskriptif kualitatif, karena peneliti mendeskripsikan data-data yang telah diperoleh berdasarkan analisis. Pendekatan kualitatif bersifat deskriptif berpandangan bahwa semua hal yang berkaitan dengan system tanda adalah penting dan memiliki pengaruh antara yang satu dengan yang lainnya. Dengan mendeskripsikan system tanda akan memberikan suatu pemahaman yang komprehensif mengenai apa yang sedang dikaji (Semi, 1993 : 30). 
Sumber data dalam penelitian ini adalah novel SHC karya Boy Candra dan novel $\mathrm{H}$ karya Tere Liye. Data yang akan digunakan dalam penelitian ini adalah kalimat yang mengekspresikan adanya unsur intrinsik dan hubungan intertekstualitas pada novel SHC dan H. Teknik pengumpulan data yang digunakan dalam penelitian ini adalah membaca secara berulang-ulang dengan teliti, kemudian menyiapkan lembar pengumpulan data, lalu mencatat data-data yang berisi hubungan intertekstual.

Alat pengumpulan data yang digunakan adalah peneliti sendiri dan tabel (Siswantoro, 2016 : 73). Peneliti bertugas sebagai pelaksana, pengumpul data, penafsir data, dan pelapor hasil penelitian. Selain itu, peneliti juga memerlukan tabel dan catatan untuk memudahkan proses pengumpulan data. Adapun teknik analisis data, dilakukan dengan pengelompokan data, mengklasifikasi data, mengkode data, dan menginterpretasi data serta mendeskripsikan data (Semi, $1993: 15$ ).

Selanjutnya untuk menguji kesahihan data, peneliti menggunakan validitas semantic. Validitas semantis adalah yaitu mengukur tingkat kesensitifan makna simbolik yang bergelanyut dalam konteks. Dimana pengukuran makna simbolik tersebut dikaitkan dengan konteks karya sastra dan konsep analisis. Sehingga dalam penelitian ini, teknik pengujian kesahihan data dapat dilihat dari sejauh mana peneliti mendeskripsikan setiap makna dari kalimat-kalimat yang diprediksi memiliki hubungan intertekstualitas (Endaswara, $2003: 164$ )

\section{HASIL DAN PEMBAHASAN}

Penelitian ini membahas dua masalah, yakni hipogram dan transformasi pada tema dan alur dalam novel SHC dan H. Karena melalui hasil analisis tersebut dapat dideskripsikan hubungan intertekstualitas dalam novel SHC dan $\mathrm{H}$.

\section{a. Tema}

Hasil analisis pertama yaitu mengenai tema, dimana kedua novel tersebut memiliki keterkaitan yang kuat. Tema dalam kedua novel tersebut adalah tentang cinta dan melupakan. SHC dan H, menjadikan hujan sebagai simbol kenangan yang mengingatkan tokoh utama terhadap hal-hal yang berarti dalam hidupnya.

Novel SHC menceritakan aku (tokoh utama) yang berusaha melupakan sosok sahabat perempuan yang dicintainya. Tokoh aku menceritakan bahwa dia memiliki kenangan-kenangan indah saat hujan bersama orang yang dicintainya. Namun di akhir waktu, kenangan-kenangan bersama hujan tersebut menjadi kenangan paling buruk dalam hidup si aku. Sampai si aku ingin melupakan semua kenangankenangan tersebut.

Novel H menceritakan sosok Lail seorang perempuan yang hidup pada tahun 2050. Dimana kejadian-kejadian indah dan buruk dalam hidup Lail terjadi pada saat hujan. Lail kehilangan orang tua, menjadi yatim piatu, bertemu Esok (pujaan hatinya), relawan kemanusiaan yang hebat, semua terjadi pada saat hujan. Hingga pada akhirnya ada kenangan buruk Lail bersama Esok yang membuat Lail ingin menghapus semua kenangannya melalui mesin penghapus ingatan.

(1) Hujan juga datang membawa pulang kehangatanmu di kepalaku. Sementara tubuhku harus tabah menikmati dinginya waktu. Namun, demi 
semua hal yang sudah kita sepakati. Aku pun mngerti, aku harus sabar menanti. Aku harus memperjuangkan apa-apa yang kumiliki. (SHC: 3)

(2) Hujan gerimis membungkus kota. Lail tersengal, duduk di atas trotoar. Wajahnya pucat. Dia baru saja melewati kengerian yang tidak pernah bisa di bayangkan sebelumnya.... (H:29)

Berdasarkan data (1) dan (2) merupakan tema minor dalam novel SHC dan $\mathrm{H}$. Kenangan bersama hujan yang dimiliki kedua tokoh tersebut hampir memiliki kisah yang sama. Dalam novel SHC hujan memiliki kenangan tokoh aku yang harus sabar dan tabah menanti tambatan hatinya untuk kembali kepelukannya. Sedangkan pada novel $\mathrm{H}$, hujan pertama menceritakan jalan hidup tokoh Lail yang baru saja diselamatkan oleh Esok dari bencana alam yang merenggut nyawa kedua orang tuanya. Dimana setelah Lail menjadi yatim piatu, Esok lah yang mengisi hariharinya.

(3) Dulu, bersamamu aku menyukai hujan. Aku suka memainkan butir hujan di jari-jari. Menyekakan ke pipimu. Lalu, kamu tersenyum - sesekali juga cemberut. Atau, pada saat-saat lain, kita sengaja membelah jalanan di tengah hujan. Menikmati rintih langit yang sedih. Aku selalu suka suasana seperti iu. Selalu suka menikmati saat hujan turun bersamamu. (SHC : 13-14)

(4) Hujan turun. Lail selalu suka hujan. Senja ini dia membiarkan tubuhnya basah di tengah udara dingin, menatap tikungan jalan, tempat sepeda merah Esok hilang di kejauhan. Usianya saat itu baru empat belas tahun, Esok enam belas. Lail belum tahu perasaanya, masih beberapa tahun lagi. Tapi saat itu dia tahu, Esok akan selalu penting baginya. (H : 91)

Data (3) dan (4) menunjukkan tema minor yang kedua yakni hijan memiliki kenangan yang indah bagi kedua tokoh dalam novel SHC dan H. Dalam novel SHC tokoh aku dan pujaan hatinya dengan sengaja menikmati hujan dengan berkeliling. Sedangkan pada novel $\mathrm{H}$, tokoh Lail pernah menghabiskan waktu bersama Esok saat Hujan, dimana saat itu Lail mulai menikmatinya hidupnya di pati asuhan. Lail mencuri waktu untuk bermain hujan bersama Esok di gerbang panti asuhan setelah sekian lama tidak bertemu dikarenakan Esok yang sudah di angkat anak oleh walikota harus menyelesaikan sekolahnya di luar negeri.

(5) Setelah berfikir panjang, aku memilih untuk meninggalkanmu. Bukan karena aku tidak lagi mencintaimu. Bukan juga karena ketabahanku sudah habis. Aku hanya ingin menghargai diriku sendiri. Hidup bersama seseorang yang tidak menghargai perasaanmu akan terasa menyedihkan. Itulah alasan aku menyudahi segalanya. (SHC : 130-131)

(6) ...tak ada satupun yang ditutupi. Apakah Esok sekarang telah berubah? Apakah dia menyukai gadis lain diluar sana? Menyukai Claudia? Mungkin sudah waktunya dia belajar melupakan Esok. enam bulan berlalu, itulah yang membuat Lail lebih sering melamun. (H : 257).

Data (5) dan (6) menunjukkan tema minor bahwa dalam kedua novel tersebut kedua tokoh berusaha saling melupakan kenangan-kenangannya. Tokoh aku dalam 
SCH belajar menghargai dirinya sendiri yang terlalu lama diperbudak oleh perasaan, sehingga mulai bangkit dari kisah-kisah masa lalu bersama pujaan hatinya. Sedangkan tokoh Lail dalam novel $\mathrm{H}$ kecewa juga mulai melupakan pujaan hatinya karena merasa kecewa dan diacuhkan.

(7) Kamu tak tahu, atau memang sengaja terlihat tak tahu. Diam-diam aku memeluk seтиa kesedihan atas apa-apa yang pernah kaтu sudahkan. Kamu menyimpan dan menyempatkan mengingat sesuatu yang lama di hidupmu. Sesuatu yang dulu mungkin lebih berarti dari apapun bagimu. (SHC : 204)

(8) Di detik terakhir, sebelum mesin bekerja Lail memutuskan memeluk erat semua kenangan itu. Apapun yang terjadi, Lail akan memeluknya eraterat, karena itulah hidupnya. Seluruh benang merah berubah menjadi biru. Seketika. $(H: 314)$

Data (7) dan (8) menggambarkan tema mayor dalam kedua novel. Kedua tokoh sama-sama memutuskan untuk memeluk kenangan masa lalu. Karena apapun yang terjadi dalam kehidupan manusia adalah takdir, sesuatu yang sangat berarti dan harus dijalani tanpa perlu disesali.

Berdasarkan data-data tersebut, diperoleh kesimpulan bahwa novel SHC dan $\mathrm{H}$ dibangun dari tiga tema minor. Tema minor yang pertama menggambarkan hujan mengingatkan kenangan buruk bagi tokoh, kedua menggambarkan hujan memiliki kenangan indah, ketiga menggambarkan kedua tokoh berusaha melupakan seluruh kenangannya. Sedangkan tema mayor dalam kedua novel adalah memeluk kenangan masa lalu. Sehingga kedua novel tersebut sama-sama memiliki tema tentang cinta dan melupakan. Bedanya, dalam novel H dibumbui tentang keluarga dan persahabatan.

b. Alur

Alur yang digunakan dalam novel SHC dan $\mathrm{H}$ adalah alur campuran. Novel SHC menggambarkan kenangan-kenangan tokoh utama dalam bentuk catatan seperti buku diari. Setiap catatan cerita selalu diakhiri dengan tanggal, bulan, dan tahun. Sedangkan novel H menggambarkan kenangan-kenangan tokoh utama dalam bentuk cerita yang dipantau dari mesin penghilang ingatan.

(9) Agar aku bisa menikmati senja, juga hujan-hujan yang pernah kita jalani. Membuatku merindu buta. Semoga segala hal yang kita jalani kini. Seberat apa pun usaha menjaga hati. Tidak hanya menjadi lelah yang berarti.

Boy Candra / 13/02/2015. (SHC : 4)

(10) “21 Mei 2024," Elijah berkata takzim. "itu hari yang tidak bisa kita lupakan..." (H:19)

Data (9) dan (10) merupakan awal perkenalan dari kedua tokoh dalam novel. SHC menggambarkan tokoh aku merindukan segala sesuatu yang berhubungan dengan pujaan hatinya, tentang hujan dengan segala sesuatu yang menjadi kenangannya. Sedangkan novel $\mathrm{H}$ menggambarkan tokoh Lail yang mulai menceritakan dimana tahun tersebut adalah tahun yang sangat berarti bagi 
hidupnya. Tahun tersebut adalah hari pertama ia masuk sekolah, terjadi bencana alam yang dahsyat, hingga terenggutnya nyawa kedua orang tuanya.

(11) Sejujurnya aku adalah orang yang paling patah saat kamu menginginkan kita pisah.... (SHC : 27)

(12) Ibunya meninggal di lorong kereta bawah tanah, dan sekarang apa yang akan ia lakukan tanpa ayahnya? Mata Lail berkaca-kaca. Butir air menggenang di sudutnya, membesar, lantas jatuh mengalir di pipi. Lail selalu suka hujan. Dalam hidupnya, seluruh kejadian sedih, seluruh kejadian bahagia, dan seluruh kejadian penting terjadi saat hujan. ( $H$ : 47)

Data (11) dan (12) permasalahan mulai muncul dalam cerita. Novel SHC menggambarkan kekecewaan, kesedihan, dan kepedihan tokoh aku yang mengharapkan pujaan hatinya kembali. Sedangkan novel $\mathrm{H}$ menggambarkan kekecewaan, kesedihan dan kepedihan tokoh Lail yang merenungi semua kejadian hidupnya serta telah menjadi yatim piatu yang mengharuskannya tinggal di panti asuhan setelah tenda pengungsian resmi ditutup.

(13) Apa yang aku takutkan akhirnya terjadi juga. Kini pelan-pelan kamu menghilang dari hidupku. Kedekatan kita yang dulu, sekarang hanya kenangan yang kusimpan dengan sendu. Canda dan tawa masih lekat di memoriku. Namun, tubuhmu kini sudah terlalu jauh. Dibawa oleh kesibukanmu bersama orang yang kau sebut kekasihmu. (SHC : 63).

(14) ...di jok belakang Lail berpegangan erat. Matanya berair. Sejak tadi ia menahan tangis. Dia berusaha ikut senang mendengar kabar itu. Sudah setahin di tinggal bersama Esok. semua peghun tenda pengungsian bahkan hafal; dimana ada Esok, berarti ada Lail, dan sebaliknya, jika ada Lail, berarti ada Esok bersamanya. ( $H: 75)$

Data (13) dan (14) menggambarkan konflik, dimana dalam SHC pujaan hati tokoh aku semakin menjauh dari hidup sang tokoh. Hal ini dikarenakan sang pujaan hati telah disibukkan hari-harinya bersama kekasih barunya. Sedangkan pada novel $\mathrm{H}$, ketika Esok diangkat menjadi anak oleh wali kota. Esok harus keluar kota untuk menempuh pendidikannya serta meninggalkan Lail seorang diri.

(15) ..., aku ingin mencintaimu lebih lama. Memberimu hati sekali lagi. Namun, luka tak mau lagi menerima. Ia memilih lebih baik kamu pergi. Semua kebersamaan yang pernah kita lewati, biarlah kusimpan dalam hati... (SHC : 89).

(16) ...mengingat Esok. apa kabar Esok? sudah lama mereka tidak bertemu, sejak Esok berangkat ke ibu kota. Ini sudah libur panjang, mungkin Esok sedang tenggelam dalam proyek penelitian, tidak bisa pulang ke kota mereka. $(H: 124)$

(17) Kenapa Esok tidak memberitahunya bahwa dia akan diwisuda tiga bulan lagi? Kenapa Esok selama ini tidak pernah meneleponya? Dan pertanyaan paling penting adalah : apakah Esok menyukainya seperti dia menyukai Esok?. (H : 228-229). 
Data (15) - (17) menunjukkan konflik semakin memanas, SHC menekankan tokoh aku yang sebelumnya belum bisa melepaskan semua kenangan tentang tambatan hatinya mulai mencoba untuk merelakannya. Sedangkan $H$ menggambarkan keadaan Esok yang mulai jarang menghubungi atau memberi kabar pada Lail. Bahkan saat Esok akan wisuda pun Lail orang paling terakhir yang mengetahui kabar tersebut.

(18) Setelah berfikir panjang, aku memilih untuk meninggalkanmu. Bukan karena aku tidak lagi mencintaimu. Bukan juga karena ketabahanku sudah habis. Aku hanya ingin menghargai diriku sendiri. Hidup bersama seseorang yang tidak menghargai perasaanmu akan terasa menyedihkan. Itulah alasan aku menyudahi segalanya. (SHC : 130-131)

(19) Lihatlah, Esok lebih banyak menghabiskan waktu bersama keluarga angkatnya. Juga menyapa teman-teman sekampusya. Dan yang membuat Lail semakin cemburu, Esok lebih sering berbicara dengan Claudia. Berfoto bersama Claudia. Bergurau dengan Claudia. Tertawa. Mereka terlihat sangat akrab. $(H: 244)$.

(20) ... tak ada satupun yang ditutupi. Apakah Esok sekarang telah berubah? Apakah dia menyukai gadis lain diluar sana? Menyukai Claudia? Mungkin sudah waktunya dia belajar melupakan Esok. enam bulan berlalu, itulah yang membuat Lail lebih sering melamun. ( $H$ : 257).

Data (18) - (20) menggambarkan klimaks dari kedua novel. Tokoh aku dalam SHC memilih meninggalkan perasaannya untuk pujaan hatinya. Ia belajar menghargai dirinya sendiri yang terlalu lama diperbudak oleh perasaan. Sedangkan novel $\mathrm{H}$ menggambarkan kekecewaan dan kecurigaan Lail terhadap Esok. Lail kecewa diabaikan Esok pada hari wisuda Esok, padahal Lail rela berangkat ke ibu kota untuk merayakan kelulusan tersebut. Puncak kekesalan Lail saat perhatian Esok harus terbagi kepada Claudia anak wali kota yang secara tidak langsung adalah adik angkat Esok. Rasa cemburu Lail pun semakin kuat, saat enam bulan setelah wisuda Esok juga belum menghubunginya sama sekali.

(21) Percayalah, saat kamu menjadikan dirimu menarik, akan selalu ada orang yang menarik mendatangimu. Dan pahamilah, kamu tidak bisa memaksa seseorang bertahan denganmu, tapi kamu selalu bisa membuat dirimu menjadi menarik agar dia tetap mempertahankanmu. (SHC : 162)

(22) Claudia resmi sudah memperoleh tiket itu. Pagi tadi walikota dan istrinya mengantar Claudia ke stasiun kereta, menuju ibu kota. (H:302).

Data (21) dan (22) menunjukkan puncak klimaks. Tokoh dalam SHC menyadari tidak bisa memaksa seseorang untuk selalu disisinya. Sedangkan dalam $\mathrm{H}$, saat Claudia resmi memperoleh tiket pesawat ulang alik menuju luar angkasa. Tere Liye dalam novel Hujan membuat latar belakang tahun 2050-an dimana bumi mulai rusak oleh keserakahan manusia. Sehingga mengharuskan manusia hidup di luar angkasa untuk mencari keselamatan. Namun hanya beberapa orang yang beruntung yang bisa mendapatkan tiket tersebut dan Lail bukan salah satu orangnya. 
Esok mendapatkan dua tiket atas jasanya dalam membantu membuat kapal ulang alik luar angkasa tersebut. Dan salah satu tiketnya diberikan kepada Claudia atas permintaan ayah angkatnya. Hal ini membuat Lail begitu kecewa dan berniat menghapus seluruh ingatannya tentang Esok.

(23) Kamu tak tahu, atau memang sengaja terlihat tak tahu. Diam-diam aku memeluk semua kesedihan atas apa-apa yang pernah kamu sudahkan. Kamu menyimpan dan menyempatkan mengingat sesuatu yang lama di hidupmu. Sesuatu yang dulu mungkin lebih berarti dari apapun bagimu. (SHC : 204)

(24) Di detik terakhir, sebelum mesin bekerja Lail memutuskan memeluk erat semua kenangan itu. Apapun yang terjadi, Lail akan memeluknya eraterat, karena itulah hidupnya. Seluruh benang merah berubah menjadi biru. Seketika. (H : 314)

Data (23) dan (24) menggambarkan penyelesaian klimaks. Kedua tokoh utama dalam novel, sama-sama memutuskan untuk memeluk kenangan masa lalu. Karena apapun yang terjadi dalam kehidupan manusia adalah takdir, sesuatu yang sangat berarti dan harus dijalani tanpa perlu disesali.

(25) Hingga aku menyadari, kamu adalah orang terpenting dalam hidupku. Tetaplah menjadi teman baik. Menjadi sahabat yang selalu memeluk erat saat aku mulai tak lagi kuat. Menjadi kekasih terhebat yang menemani melalui fase-fase sulit dalam hidup. Bersamamu ingin kuhadapi segalanya sampai waktu menutup usia kita. (SHC : 236)

(26) Kutipan yang dibaca Maryam benar... kemampuan mereka memeluk erat-erat... (HTL : 317).

Data (25) dan (26) menggambarkan tahap penyelesaian kedua novel yang berakhir happy ending. Semua kehidupan harus dilalui dengan perjuangan, meskipun harus rela merasakan kecewa, kepedian, dan kesedihan terlebih dahulu.

Berdasarkan data-data yang telah diperoleh, dalam novel SHC dan H terdapat delapan tahapan dalam cerita. Tahap pertama adalah tahap perkenalan, kedua permasalahan mulai muncul, ketiga munculnya konflik, keempat konflik mulai memanas, kelima puncak konflik, keenam tahap penyelesaian konfik, terakhir tahap penyelesaian cerita. Tahapan-tahapan tersebut menunjukkan alur cerita berdasarkan kriteria waktu. Sedangkan alur cerita berdasarkan kriteria isi, novel SHC dan H termasuk plot peruntungan. Karena seluruh isi cerita berdasarkan nasib dan peruntungan tokoh utama.

\section{SIMPULAN}

Novel SHC dan $\mathrm{H}$ dibangun dari tiga tema minor. Tema minor yang pertama menggambarkan hujan mengingatkan kenangan buruk bagi tokoh, kedua menggambarkan hujan memiliki kenangan indah, ketiga menggambarkan kedua tokoh berusaha melupakan seluruh kenangannya. Sedangkan tema mayor dalam kedua novel adalah memeluk kenangan masa lalu. Sehingga kedua novel tersebut sama-sama 
memiliki tema tentang cinta dan melupakan. Perbedaan dalam novel $\mathrm{H}$ dibumbui tentang keluarga dan persahabatan.

Alur dalam novel SHC dan H terdapat delapan tahapan dalam cerita. Tahap pertama adalah tahap perkenalan, kedua permasalahan mulai muncul, ketiga munculnya konflik, keempat konflik mulai memanas, kelima puncak konflik, keenam tahap penyelesaian konfik, terakhir tahap penyelesaian cerita. Tahapan-tahapan tersebut menunjukkan alur cerita berdasarkan kriteria waktu. Sedangkan alur cerita berdasarkan kriteria isi, novel SHC dan $\mathrm{H}$ termasuk plot peruntungan. Karena seluruh isi cerita berdasarkan nasib dan peruntungan tokoh utama.

Berdasarkan bukti data-data yang diperoleh peneliti tersebut, kajian intertekstual bisa digunakan sebagai bahan ajar siswa dalam menulis karya sastra. Meskipun setiap orang memiliki latar belakang soial yang berbeda, bisa dipastikan ada beberapa hal kesamaan yang dimiliki seseorang dengan orang lain. kesamaan tersebut bisa terlihat dari jenis kelamin, tempat kelahiran, kesamaan pendidikan, pengalaman, ataupun guru yang mengajar sewaktu di sekolah.

Siswa yang diajar oleh guru yang sama, dengan materi yang sama memungkinkan memiliki kesamaan dalam hasil karyanya meskipun secara tidak sengaja. Karena dalam memberikan contoh sebuah materi mata pelajaran, seorang guru akan memberikan contoh yang sama persis kepada seluruh siswa. Tidak mungkin guru memilih contoh materi kepada siswa dengan contoh yang berbeda-beda. Sehingga dengan jelas dapat dipastikan kajian intertekstual bisa digunakan sebagai alternative bahan ajar menulis sastra.

\section{DAFTAR RUJUKAN}

Bandung, SDM 7 (2018). Kenapa dipanggil Tere Liye? Talk Show Kepenulisan Bersama Tere Liye. Youtube : https://youtu.be/MGPTO_Z9Mz8

Candra, B. (2015). Senja, Hujan, dan Cerita yang Telah Usai. Jakarta : Mediakita

Endaswara, S. (2003). Metodologi Penelitian Sastra. Yogyakarta : Media Pressindo

Grobmart.com (2018). Lebih Dekat dengan Boy Candra. Youtube : https://youtu.be/LBSfyhCDnNg

Kristeva, J. (1986). Word, Dialogue and Novel. New York : Columbia University Press.

Kusuma, K.A. Waluyo, H.J. Wardani, N.E (2018). Pengakuan Calabai : Sebuah Analisis Intertekstual Novel Pasung Jiwa Karya Okky Madasari dan Novel Calabai karya Pepi Al-bayqunie : Jurnal Kata. Vol. 2 (1) Mei. Universitas Sebelas Maret.

Liye, T. (2016). Hujan. Jakarta : PT Gramedia Pustaka Utama

Nurgiyantoro, B. (1995). Teori Pengkajian Fiksi. Yogyakarta : Gadjah Mada University Press 
Rokhmansyah, A. (2014). Studi dan Pengkajian Sastra : Perkenalan Awal terhadap Ilmu Sastra. Yogyakarta : Graha Ilmu

Sungkowati, Y. (2014). Hubungan Intertekstual Drama "Antara Bumi dan Langit (Kemuning Diwaktu Dahulu)” dengan Novel Belenggu : jurnal Salingka. Vol. 11 (1) Juni. Sidoarjo : Balai Bahasa Jawa Timur

Uniawati. (2014). Pengaruh Cerita Laskar Pelangi Terhadap Negeri 5 Menara-Kajian Intertekstual : Jurnal Ilmiah Metasastra. Vol. 7 (2) Desember 2014, hlm 227-240. Kendari : Balai Bahasa Provinsi Sulawesi Tenggara 
Mitasari. Intertekstual Novel Senja, Hujan dan Cerita yang Telah Usai ... 